\title{
DETERMINANTS OF ACCESS AND EXTENT OF USE OF AGRICULTURAL INSURANCE SCHEMES BY SMALL-SCALE FARMERS IN KOGI STATE, NIGERIA
}

\author{
Benjamin Chiedozie OKPUKPARA (iD, Ikenna Charles UKWUABA* (D), Olusegun ADEBAYO (D)
}

\author{
Address: \\ Department of Agricultural Economics, Faculty of Agriculture, University of Nigeria Nsukka, 410001, Enugu State, \\ Nigeria. \\ * Corresponding Author: ikenna.ukwuaba@unn.edu.ng
}

\begin{abstract}
Research Background: Although, insurance services are offered by the Nigerian Agricultural Insurance Corporation and other private companies in Nigeria; however, there has been a low level of involvement of farmers in the purchasing of insurance premiums in Kogi state. The empirical evidence on the factors accountable for the low patronage of the Nigeria Agricultural Insurance Schemes (AIS) in Kogi State are not known. The identification of these factors inhibiting the access and use of AIS by farmers and the provision of appropriate and efficient solutions by the relevant stakeholders can mitigate the catastrophic effects of risks and uncertainties on the farmers.

Purpose of the article: The research was carried out in order to ascertain the determinants of access and extent of use of AIS by farmers in the study area so as to of provide appropriate and efficient solutions capable of mitigating the catastrophic effects of risks and uncertainties inherent in agriculture on the farmers means of livelihood. This makes the analysis of the level of access and extent of use of and the factors influencing farmers' willingness to participate in the agricultural insurance scheme a compelling necessity.

Methods: Data for the study was collected through the help of a well-structured questionnaire administered to 150 farmers whom were selected through a multi-stage random sampling technique. Data collected were analysed using descriptive statistics and Heckman's two-stage model.

Findings and value added: Farmers in the study area were males, literate, and experienced farmers. The determinants of access to AIS were awareness of AIS, age, income, and marital status, while age, awareness of AIS, and income significantly influenced the extent of use of AIS by the farmers in the study area. Farmers in the study area can access and use more of AIS through increased awareness of the insurance scheme as well as increasing farmers' income level through affordable loan scheme or outright government grants.
\end{abstract}

Key words: insurance; Heckman model; risks; small scale farmers; Nigeria JEL Codes: Q12; Q14; Q18

\section{INTRODUCTION}

Insurance is a method of risk management used to protect against contingent loss. It is conventionally defined as a fair transfer of risk of loss from one entity to another in exchange for a premium or a guaranteed and quantifiable small loss to prevent a large and possibly devastating loss (Schaffnit-Chatterjee, 2010). Specifically, according to Epetimehin (2012), agricultural insurance is intended to cover financial losses incurred due to an unforeseen decline in agricultural production. The primary aim of any agricultural insurance policy is to act as cover for losses from natural disasters; it also serves as collateral for formal financial institutions' agricultural loans to farmers (Pelka et al., 2015). Agricultural insurance policy is one of the prominent strategies used by farmers to reduce, share, or pass the risks and uncertainties inherent in their farming business. It encourages farmers to invest more in agricultural production, promotes their trust in the adoption of new and enhanced farming methods, enhances their access to credit through financial institutions as insurance cover, and ultimately provides financial support to farmers in the form of compensation that ensures the sustainability of their farming activities. (Eleri. et al., 2012). In cognizance of the need for a clear support program for agricultural growth which addresses the peculiar problems of risks and uncertainties, the Nigerian Agricultural Insurance Scheme (NAIS) was administered by the Nigerian Agricultural Insurance Company (NAIC) was introduced. The key goal of the scheme was to reduce to an acceptable minimum the catastrophic effects of agricultural risks as well as natural disasters and ensuring payment of adequate compensation to keep farmers in business. (Aina and Omonona, 2012). Many private insurance firms have also arisen in Nigeria over the years, integrating agricultural insurance into their policies (Aina and Omonona, 2012). However, there is still a very limited provision of agricultural insurance across rural banking networks, including microfinance institutions (Mahul and Stutley, 2010). In a report by the Nigerian 
Agricultural Insurance Scheme; Aina and Omonona ( 2012) reported that though the scheme has been beneficial to the few farmers that keyed into the insurance program, ,there exist some bottlenecks which includes but not limited to lack of fund, lack of trained personnel, low penetration of the scheme, low participation of commercial banks in agricultural finance, lack of interest in the scheme by insurance companies and difficulties in developing new agricultural insurance products. Mahul and Stutley (2010) reported, in agreement with Yusuf's findings, that government-sponsored agricultural insurance programs and farmers' participation were disappointing. Therefore, the consequences in the absence of risk management tools such as insurance may lead farmers out of production. Also, the successive government has introduced various incentives programs to ensure the patronage of agricultural insurance, sustained and beneficial to the insurer; this effort, however, has not made much impact (Akinola, 2014). Similarly; in India, Chhikara and Kodan, (2012) observed that the majority of rural farmers were hindered from accessing the national agricultural insurance scheme, and as a result, they are compelled to cope with the use of conventional methods for risk minimization which were not so effective and reliable. Furthermore, Mahul and Stutley (2010) noted that from the perspective of most subsistence farmers, agricultural insurance is seen as a luxury in which few farmers could only afford; hence, farmers seek effective and efficient government intervention to make agricultural insurance more affordable through premium subsidies. Sikibo et al. (2018) agreed that while awareness of agricultural insurance is a crucial precursor to its use, only a few farmers understand how it works; this prohibits their ability to make decisions on its use. The adoption was also impeded by the unaffordability of premiums and inaccessibility of insurance services (Chantarat $\boldsymbol{e t}$ al., 2013).

Although, insurance services are offered by the Nigerian Agricultural Insurance Corporation and other private companies in Nigeria, however, there has been a low level of involvement of farmers in the purchasing of insurance premiums and, consequently, there is a need to analyse limiting factors to the use of agricultural insurance scheme. Furthermore, even though Kogi State is predominantly an agrarian state, researches on agricultural insurance and its accessibility by farmers are limited in the literature. Previous studies, by Adah et al. (2016), centred on the evaluation of rural farmers' attitudes towards the agricultural insurance scheme as a risk management tool in Kogi State while Ibitoye (2012) concentrated on assessing the level of knowledge and use among rural farmers of the agricultural insurance scheme. However, little or no work has addressed the determinants of access and extent of usage of agricultural insurance schemes by small-scale farmers in Kogi State.

The broad objective of this paper is to examine the determinants of access and extent of use of agricultural insurance schemes by small-scale farmers in Kogi state, Nigeria. The specific objectives are to:

$i$. describes the socioeconomic characteristics of the smallscale farmers, ii. examines the socio-economic factors that influence access to Agricultural Insurance Scheme by small-scale farmers and iii. identify factors that determine extent of use of Nigerian Agricultural Insurance Scheme by small scale farmers Based on the stated objectives, two hypotheses were drawn; i. $\mathrm{H}_{01}$ : Socio-economic characteristics of farmers have no influence on access to Nigerian Agricultural Insurance Scheme by farmers, and ii. $\mathrm{H}_{02}$ : Socio-economic factors have no influence on the extent of use of Nigerian Agricultural Insurance Scheme by farmers.

\section{LITERATURE REVIEW}

Small scale farmers in most developing counties especially those in Sub Saharan Africa are particularly vulnerable to climate shocks; but unfortunately, have little or no access to agricultural insurance (Sibiko et al., 2018). Formal insurance contracts are seldom available for the small-scale resource- poor farmers in the rural areas of low - income countries (Chantarat et al., 2013). The high risk associated with agriculture which includes but not limited to flood, drought, pest infestation and diseases, price and policy volatility among others, which results in crop failure and sometimes in total loss of the source of livelihood. Many smallholder farmers in Kogi state, Nigeria face these risks, and thus, it has become increasingly necessary that these farmers take formal insurance to mitigate the risks and uncertainties that come with farming.

Agricultural insurance is designed to provide covers for financial losses incurred due to variability in the expected outputs. Insurance is a vital part of the risk management task, as it helps to determine who carries, which part and how much of a risk. This enables equitable risk-sharing and also ensures that correct levels of cover are taken out by the right parties, based on ability to pay. Premium is the price the farmer pays monthly or per annum. Skees (2008), as well as Nnadi et al. (2013), affirmed that traditional risk minimization strategies are unfavourable to some extent and cannot adequately absorb the resultant economic shocks; hence, can lead to a poverty trap. Therefore, risk transfer using insurance works best where and when other complimentary services are in place, such as access to credit, improved seeds and inputs, markets and functioning supply chains, and advisory services.

Several empirical works of literature on agricultural insurance indicated that socio-economic characteristics of farmers generally affect their awareness, access and also use (participation) of agricultural insurance schemes. Nnadi et al. (2013), focused on the socio-economic differentials of participants and non-participant. The result revealed that there were socio-economic differentials in the age, education, farming experience, social organization membership, the status of participants and non-participants in the scheme. The study further revealed that the socio-economic and farm enterprise characteristics of age, education, marital status, farming status, farming experience, farm size and credit opportunity were significant in determining the farmers that participated in the scheme. Sherrick et al. (2004) in 
the Midwestern states of Illinois, Iowa and Indiana, United States oriented on the factors influencing farmers' crop insurance decisions indicated that farm size, age, perceived yield risk, and income of the household were among the major variables that significantly influenced farmers' decision to use agricultural insurance. Similarly, Falola et al. (2013) examined willingness to take agricultural insurance by cocoa farmers in Nigeria, the study also identified age of household head, educational level, and access to extension service and farm income as the various socio-economic factors that significantly influenced willingness to take agricultural insurance. Kumar et al. (2011) analysed farmers' perceptions and awareness towards crop insurance as a tool for risk management using Tobit and Probit models. The result of the survey showed that $65 \%$ of the farmers were aware of risk mitigation measures. Chikaire et al. (2015) studied rural farmers' perception, awareness and use of agricultural insurance as a hedge against climate change, the study revealed that the majority of the farmers $(87.3 \%)$ had no knowledge of agricultural insurance opportunity in the study area, and $75 \%$ indicated interest if they can access it. The result further revealed that only $7.7 \%$ and $5 \%$ were very much aware and partially aware as well, the study concluded that the majority in the study area who are farmers were not aware of the agricultural insurance scheme in Nigeria and that could be due to low level of education and lack of publicity/campaign on insurance among the rural dwellers. The study further posed that the farmers had a positive perception for agricultural insurance, that if made available, would reduce risk and set back, cushion shock arising from losses, increase credit worthiness and reduce vulnerability as well and such indicated interest. Furthermore, Nwani (2019) revealed that the farmers had an unfavourable perception of agricultural insurance, as a result of the obstacles arising from their low level of education, lack of awareness and also communication gaps that existed between these farmers and appropriate stakeholders.

The conclusion drawn from these researches could imply that a relationship exists between farmers' awareness and perception of agricultural insurance which can be positive or negatively significant. For instance, in research in Eastern Ghana, Ellis (2017) found a positive and significant association between farmers' awareness and perception of agricultural insurance. Similarly, Akinola (2014) in his study on determinants of farmers' adoption of agricultural insurance in Ogun State Nigeria noted that only $46 \%$ of farmers had knowledge of agricultural insurance policy and only $44 \%$ adopted the practice. The author concluded that rate of farmers' adoption of agricultural insurance practice would increase if there is an increase in both the formal and extension education, an improved awareness of agricultural insurance policy, more perception and concern for experience with risk and less indifference resulting from too much confidence in their years of farming experience and alternative risk management strategies.

Chantarat et al. (2013) noted that the number of smallholder farmers taking crop insurance is marginally small. The study further revealed that the insurance pattern was complicated by the fact that the majority of households did not understand the insurance concept, partially because of the complex nature of insurance or because there was not sufficient awareness on the side of the farmers. This supports the study by Mahul and Stutley (2010), that the general population views insurance coverage as a privilege of the rich, which is particularly true for agricultural insurance, which, by definition, pays only when infrequent events occur. The poor in developing countries are the most exposed to and affected by natural hazards and they have limited or no access to insurance and financial services and in most cases have to manage weather risks by their means (Hallegatte et al., 2020). Sibiko et al. (2018), similarly observed that the majority of smallholders are precluded from accessing agricultural insurance services and as a result, they are pushed to cope with disasters using traditional risk minimization strategies, yet they cannot adequately cushion them from the effects of reduced productivity and income losses. Despite substantial research efforts to enhance smallholder access to formal insurance services through innovation in financial derivative insurance products, emerging evidence globally (Cole et al., 2013). Tsikirayi et al. (2014) demonstrate that the uptake of index insurance has been generally low, though there are promising results concerning its demand and impacts on key household indicators. Thus, ease of access to farming clients by insurers is key to the diffusion of agricultural insurance (Tsikirayi et al., 2014). Their study indicated that partnership with agricultural financial institutions and farm visits were noted as the key means of access to the farmers by insurers to create new business and maintain the existing one, and also that through the insurer/financial institutions partnerships, farmers were able to pay their insurance premiums.

A commonly cited reason for the low demand for agricultural insurance in developing countries is the limited understanding of its benefits and insurance is often perceived as a non-viable investment because premiums are collected every year but indemnities are paid much less frequently (Chantarat et al., 2013). Sikibo et al. (2018) in a study on the determinants of agricultural insurance uptake decisions in the face of climate change among smallholder farmers in Kenya, revealed that some of the major predictors that that significantly influenced the decision to buy crop weather index insurance are crop insurance awareness, training on crop insurance, cooperative membership, farm size, off farm income, education, proximity to both the nearest farm produce market and the weather station. Chikaire et al. (2015), revealed that only 3 . \% were using insurance, $21.7 \%$ indicate that if insurance is available, they would not use it and this was due to the low income of farmers. From the study, the majority $(75.3 \%)$ indicated readiness to use it once it becomes available and they showed them readiness by their response. According to Cole $\boldsymbol{e t}$ al. (2013) even with numerous efforts to avail formal insurance to farmers in low-income rural settings through pilot programmes, to date, very little success has been achieved to move index insurance beyond the piloting phase and hence the uptake levels remain low.

Generally, factors that affect the uptake of agricultural insurance are yet to be fully understood, partly because of 
lack of sufficient data and over-reliance on hypothetical evidence that seem to underscore the theoretical viability of insurance yet the empirical evidence from several insurance programmes showed mixed results on the performance of agricultural insurance. Empirical studies showed that in the access and use of agricultural insurance packages, both insurers and farmers face several distinct challenges which hinders the practice. Tsikirayi $\boldsymbol{e t}$ al. (2014), analysed the uptake of agricultural insurance services by the agricultural sector in Zimbabwe, from the result, the constraints cited by insurers and farmers as preventing high uptake of farm insurance were: limited knowledge on insurance; unaffordability of insurance; low-income levels; and low agricultural production; remoteness of farms from service providers; and negative perceptions about insurance in general. Similarly, Ogunmefun and Achike (2015), revealed that the majority of the farmers $(61 \%)$ identified their major problems with the use of informal insurance measures as entry constraints which were grouped into lack of credit, lack of credit facilities, lack of working capital (assets like land) and lack of skills (education), and also high costs of inputs as problems they encountered, thus constrained the access and use of such insurance programme in the study area. Therefore, agricultural insurance is expensive to service, particularly to small and marginal farmers scattered across the countryside (Mahul and Stutley, 2010).

\section{DATA AND METHODS}

\section{Study Area}

The study was carried out in Kogi State, Nigeria. It is located between latitude $7^{0} 49^{\prime} \mathrm{N}$ and longitudes $6^{0} 45^{\prime} \mathrm{E}$. Kogi state has 21 local Government Areas (LGAs), about 2.1 million inhabitants (FRNOG, 2009), and four agricultural zones designated as zone A, B, C, and D.

The climate is divided into two major seasons - dry and wet seasons. The wet season begins towards the end of March and ends towards the end of October. Occasionally, rainfall may not start until the month of April especially in a very dry. Dry season begins in the month of November and lasts until late February. The harmattan wind is experienced during the dry season between December and January. The average annual rainfall is between 850 and 2000 millimetres. During the rainy and dry seasons, the daily mean temperature is $280^{\circ} \mathrm{C}$ and $350^{\circ} \mathrm{C}$, respectively. High humidity is also a common occurrence (KADP, 2011). The vegetation of the state is made up of rainforest in the south and woody derived savannah and Guinea savannah in the north. The land mass is generally flat or gently undulating, and it lies between 50 and 700 meters above sea level. Generally, the land mass is flat or gently undulating and lies at $50 \mathrm{~m}$ to $700 \mathrm{~m}$ above sea level.

The two largest rivers in Nigeria Rivers Niger and Benue, which are the two major rivers in Nigeria form a confluence at Lokoja, the state capital. The rivers predispose the farm lands to occasional flooding especially during the rainy season. The effects of the flooding are usually severe and destroy many farm lands, leading to the loss of livelihood on the part of the farmers.

\section{Sampling Techniques}

Multi-stage sampling techniques were used in selecting respondents. Stage one involved a random selection of two LGAs from each of the four agricultural zones. Five communities were chosen randomly from each of the eight LGAs in stage two; while in the third stage, four smallscale farmers from each of the 40 communities were randomly selected. A total of 160 respondents were therefore chosen for the study.

\section{Data Collection}

Data were obtained from a primary source using a wellstructured questionnaire. The questionnaire was designed in such a way as to capture the specific objectives of the study. However, the questionnaire recovery rate was $94 \%$; therefore, 150 respondents were analysed out of the 160 chosen for the study.

\section{Data Analysis}

The objectives were realized using descriptive statistics such as mean, frequency, percentage, and Heckman twostage model. The Heckman two-stage model was used to determine the factors that influence access and extent of use of AIS. The access to and the extent of use of AIS are dependent on some variables which were estimated independently. For such independent estimation of two equations; the first was whether a farmer had access to AIS or not and the second was the extent of use of AIS. The model was divided into two steps; first, the selection equation was calculated using a probit model, and second, the outcome equation was calculated using OLS regression. A probit model predicts the probability of whether a farmer had access to AIS (Eq. 1).

$\operatorname{Pr}\left(Z_{i}=1 / w l \alpha\right)=\boldsymbol{\phi}(\boldsymbol{\eta}(\omega l, \alpha))+E_{i}$

Where: $Z_{i}$ is an indicator variable equivalent to unity for a farmer who had access to AIS, $\boldsymbol{\phi}$ is the regular normal cumulative distribution function, $\omega l$ is the vector of coefficient to be calculated, and $E_{i}$ is the error term presumed to be normally distributed with a mean of zero and variance $\sigma^{2}$. If the marginal utility obtained by the farmer from accessing AIS is greater than zero, the variable $Z_{i}$ takes the value of 1 , and zero otherwise. This was illustrated as Eq. 2.

$$
Z_{i}=\alpha w^{l}+U_{i}
$$

Where: $Z_{i}$ is the latent level utility the small-scale farmers get from accessing AIS,

$U_{i} \sim \mathrm{N}(0,1)$ and

$Z_{i}=1$ if $Z_{i}>0$

$Z_{i}=0$ if $Z_{i} \leq 0$

In the second step, to correct possible selection bias, an additional regressor in the equation was included. The inverse mills rational (IMR) was computed as Eq. 3 .

$$
I M R=\frac{\emptyset(\boldsymbol{\eta}(\omega\llcorner, \alpha))}{\emptyset(\omega \downarrow, \alpha)}
$$

Where: $\varnothing$ is the normal probability density function. The second stage was given by Eq. 4 . 
$\mathrm{E}=\frac{Y_{i}}{Z}=1=f\left(X_{i}, \beta\right)+\lambda \frac{\emptyset(\eta(\omega l, \alpha))}{\emptyset(\omega \iota, \alpha)}$

Where: $\mathrm{E}$, is the expectation operator density, $\mathrm{Y}$ is the (continuous) extent of Use of Agricultural Insurance Scheme (AIS), $\mathrm{X}$ is a vector of independent variables, affecting the extent of Use of AIS and $\beta$ is the vector of the corresponding coefficients to be estimated. Therefore, $Y_{i}$ can be expresses as Eq. 5 .

$Y_{i}^{*}=\beta^{1} X^{\iota}+y \lambda^{\iota}+U_{i}$

$Y_{i}^{*}$ is only observed for those farmers who have access to AIS

Where:

$U_{i} \sim \mathrm{N}(0$, бu $)$

$\left(Z_{i}=1\right)$, in which case $Y_{i}=Y_{i}^{*}$

Therefore, the model can thus be estimated as follows:

The first step of either access to AIS or not was specified as Eq. 6.

$$
\mathrm{P}(0,1)=\beta_{0} X_{0}+\beta_{1} X_{1}+\beta_{2} X_{2}+\cdots \beta X_{n}+e
$$

Where: Access was denoted by 1 and Non - access was denoted by $0, \beta_{0}$ is a Constant, $\beta_{1 \ldots n}$ are parameters to be estimated, $X_{1 \ldots n}$ are vectors of explanatory variables.

The second step which was the extent of Use of AIS was estimated by the use of an OLS as Eq. 7.

$\mathrm{Y}=\beta_{0} X_{0}+\beta_{1} X_{1}+\beta_{2} X_{2}+\cdots \beta X_{n}+e$

Where: Y denotes the extent of Use of AIS, $\beta_{0}$ is a constant, $\beta_{1 \ldots n}$ are parameters to be estimated, $X_{1 \ldots n}$ is a vector of explanatory variables.

The two equations are explicitly specified as Eq. 8-9.

Step 1: Selection equation

$$
\begin{aligned}
& \operatorname{Pr}(\mathrm{Y}=1 / X)=b_{0}+b_{1} X_{1}+b_{2} X_{2}+b_{3} X_{3}+ \\
& b_{4} X_{4}+b_{5} X_{5}+b_{6} X_{6}+b_{7} X_{7}+b_{5} X_{5}+b_{6} X_{6}+ \\
& b_{7} X_{7}+b_{8} X_{8}+b_{9} X_{9}+b_{10} X_{10}+e
\end{aligned}
$$

Step 2: Outcome equation

$Y_{i}=\mathrm{f}\left(b_{1} X_{1}+b_{2} X_{2}+b_{3} X_{3}+b_{4} X_{4}+b_{5} X_{5}+b_{6} X_{6}+\right.$ $b_{7} X_{7}+b_{5} X_{5}+b_{6} X_{6}+b_{7} X_{7}+b_{8} X_{8}+b_{9} X_{9}+$

$b_{10} X_{10}+e$

Where:

Pr denotes probability;

$\mathrm{Y}$ is the extent of Use of AIS;

$X$ is a vector of regressors which are assumed to influence the outcome $Y$

$Y_{i}$ conditional probability estimate with 1 as positive extent of use by farmers as regard the use of AIS, otherwise 0 ;

$Y_{i} 0$ for non-access to AIS;

$b_{0}$ intercept parameter;

$b_{i} \quad \ldots b_{n}$ coefficients of independent variables;

$e$ stochastic error term;

$X_{1}$ age;
$X_{2}$ gender;

$X_{3}$ awareness of AIS (yes $=1$, otherwise 0 );

$X_{4}$ farming experience (years);

$X_{5}$ household size (number);

$X_{6}$ access to credit (Access $=1$, otherwise 0 );

$X_{7}$ marital status (married $=1$, otherwise 0$)$;

$X_{8}$ cooperative membership (membership $=1$, otherwise $0)$;

$X_{9}$ past experience with risk (Positive $=1$, otherwise 0 ); $X_{10}$ monthly income (NGN).

\section{RESULT AND DISCUSSION}

\section{Socio-economic characteristics of the respondents}

The result in Table 1 showed that $73.33 \%$ of respondents were males while $26.67 \%$ of the respondents were females. This implied that male-dominated the farming activities in the area. The result could be attributed to the stressful and demanding nature of farming in developing countries where mechanical farming is not common. The marital status of the respondents showed that the majority of farmers $(68 \%)$ were married, while only a few $(8 \%)$ were single. This implied that more married people are engaged in farming in the study area. This may be because agriculture is labour intensive, requiring direct and indirect labour contributions from the members of the family to minimize the cost of paid labour. The majority $(58.01 \%)$ of respondents were between 41 and 60 years of age. The average age of the farmers was 47 , which indicates that the typical farmers studied were in the economically active age group. The results showed that farmers are young and energetic and can cope with farming demands, so they can bear the stress and take the risks involved in the farming business. The educational status of the respondents showed that the majority $(81.33 \%)$ of the respondents had formal education while only $18.67 \%$ had no formal education. The result indicated that the respondents were literate, an advantage which according to FAO (2006), could translate to higher farm management and business acumen in terms of profit rate. The result corroborates the findings of Ukwuaba $\boldsymbol{e t}$ al. (2020) who reported a high educational status among crop farmers in the Enugu Ezike Agricultural Zone of Enugu State, Nigeria. The majority $(63.33 \%)$ of the respondents engaged in crop production while a few $(9.33 \%)$ were involved in livestock production in the study area. About $27 \%$ of the respondents combined both crop production and animal farming. This could be attributed to the fact that crop production is comparatively less risky, cheaper, and easier to manage compared to livestock production. As regards their farming experience, the majority (46\%) of the respondents had between one to 15 years of farming experience while about $41 \%$ of the respondents had 16 to 30 years of farming experience; few of the respondents (13.3\%) had farming experiences above 30 years. The average years of experience were 19. This suggested that most of the people involved had been in farming for years and that agriculture was their main livelihood in the area. 
Table 1: Socio-economic characteristics of the respondents

\begin{tabular}{|c|c|c|c|}
\hline Socio-economic characteristics & Frequency & Percentage & Mean \\
\hline \multicolumn{4}{|l|}{ Gender } \\
\hline Female & 40 & 26.67 & \\
\hline Male & 110 & 73.33 & \\
\hline \multicolumn{4}{|l|}{ Marital Status } \\
\hline Single & 12 & 8.00 & \\
\hline Married & 102 & 68.00 & \\
\hline Divorced & 20 & 13.33 & \\
\hline Widowed & 16 & 10.67 & \\
\hline Age & & & 46.67 \\
\hline $20-40$ & 51 & 34 & \\
\hline $41-60$ & 85 & 58.01 & \\
\hline $61-75$ & 12 & 8.02 & \\
\hline Educational Status & & & 8.5 \\
\hline No formal education & 28 & 18.67 & \\
\hline Primary education & 35 & 23.33 & \\
\hline Secondary education & 55 & 36.67 & \\
\hline Tertiary education & 32 & 21.33 & \\
\hline \multicolumn{4}{|l|}{ Farm Type } \\
\hline Crop farming & 95 & 63.33 & \\
\hline Livestock farming & 14 & 9.33 & \\
\hline Livestock and crop & 41 & 27.33 & \\
\hline Farming experience (years) & & & 19.14 \\
\hline $1-15$ & 69 & 46 & \\
\hline $16-30$ & 61 & 40.67 & \\
\hline $31-40$ & 20 & 13.34 & \\
\hline Farm size $(\mathrm{Ha})$ & & & 3.03 \\
\hline $0.5-2.0$ & 61 & 67.34 & \\
\hline $2.1-3.5$ & 44 & 29.34 & \\
\hline $3.6-5.0$ & 32 & 21.34 & \\
\hline $5.1-8.5$ & 43 & 8.66 & \\
\hline Household size & & & 5.43 \\
\hline $1-5$ & 76 & 50.67 & \\
\hline $6-10$ & 73 & 48.66 & \\
\hline 11 & 1 & 0.67 & \\
\hline Monthly income (NGN) & & & $67,572.22^{1}$ \\
\hline $0-50,000$ & 11 & 7.32 & \\
\hline $50,001-100,000$ & 35 & 23.33 & \\
\hline $100,001-200,000$ & 104 & 69.34 & \\
\hline Total & 150 & 100 & \\
\hline
\end{tabular}

Note: ${ }^{1} 177.35$ USD. Exchange rate: 381 NGN = 1 USD as at March, 2021.

Source: Field Survey, 2018

The mean farm size of the respondents was 3.03 hectares, implying that most of the farmers were smallholders and subsistence farmers. The limited farm size may be due to the land tenure system in the study area, which makes mechanize farming unprofitable and uneconomical to employ.

About $50 \%$ of the respondents had a household size between one to five while few $(0.67 \%)$ had a household size above 11 members. The mean household size of the respondents was five persons and implied that the respondents had an available labour force to assist in the farming business. Thus, the more the household size, the greater the labour force available for farm works. However, Prager et al. (2018) reported that large households can limit the net return from the agricultural business by diverting potential investment funds to increase household expenditure. The mean monthly income of the respondents was 67,572.22 NGN (Nigerian currency Naira), (117.35USD). The result showed that an average farmer in the study area earns at least twice above the national minimum wage of $30,000 \mathrm{NGN}$ (78.74 USD) and thus improved standard of living.

Determinants of Access to the Agricultural Insurance Scheme

On the determinants of access to AIS in Kogi state, Nigeria, the result showed that awareness of agricultural insurance, age, and income was significant and positively influenced access to agricultural insurance while marital status negatively influenced access to agricultural insurance. The awareness of the scheme was significantly positive and implied that the more one is informed and aware of the existence of AIS, the more one is likely to purchase or access more of the agricultural insurance. The findings showed that an increase in the awareness 
campaign will likewise increase respondents' access to agricultural insurance. The result is consistent with the results of Akinola (2014) who reported the awareness of insurance as an important factor in accessing formal agricultural insurance in Southwest, Nigeria. The age of the respondents was significant and positively increased access to agricultural insurance. The result suggests that older respondents had more access compared to younger farmers. This may be because the older one becomes the more risk-averse one becomes. Results also showed that the total income received by the respondents also played a major role in determining access to agricultural insurance in the study area; the higher the income received by the respondents the higher the access to agricultural insurance. This implied that farmers with high-income levels tend to access more agricultural insurance compared to farmers with low income. This is understandable as the higher income farmers had a surplus income to invest in the purchase of AIS. The result is consistent with the findings of Afroz et al. (2017) in Malaysia; who reported that the farm income of a farmer is essential in accessing formal agricultural insurance as a way of mitigating the effects of climate change. However, marital status was negative and significantly influenced respondents' access to agricultural insurance. The result implied that respondents who are not married will have more access to agricultural insurance compared to married farmers. This is attributed to the fact that the married farmers have more other family responsibilities which limit the amount of money or farm income needed to purchase formal agricultural insurance.

Consequently, the results in Table 2 showed that the socio-economic characteristics significantly influenced access to Nigeria's agricultural insurance scheme by farmers. Hence, the null hypothesis was rejected and the alternative accepted. The null hypothesis 1 is rejected because the chi $^{2}$ value of 61.92 at 0.05 level of probability was higher than the tabular value of 3.845 .

\section{Determinants of the Extent of Use of Agricultural Insurance Scheme}

The result in Table 3 showed the factors that influenced the extent of agricultural insurance purchased by the respondents. Agricultural insurance awareness boosted the amount of agricultural insurance purchased. Thus, farmers who had adequate information on agricultural insurance and understand its importance will buy more agricultural insurance compared to respondents that knew little or nothing about agricultural insurance. As regards the marginal effect unit increase in the level of awareness of agricultural insurance will lead to an additional purchase of 256,893 NGN agricultural insurance. Age was also positive and significantly increase the amount of insurance purchased. In other words, the older farmers invested more in agricultural insurance than the relatively younger ones. The result shows that a unit increase in age will increase the amount of agricultural insurance purchased by $10,057 \mathrm{NGN}$ (24.54 USD). The findings agree with that of Okoffo et al. (2016) in Ghana who indicated that age was among the significant variables in the decision to pay premium for agricultural insurance among cocoa farmers. The result also showed that farmers with higher incomes purchased more agricultural insurance. This is understandable as income is an important determinant of the amount of insurance purchased. Therefore, the higher the income received the higher the amount of agricultural insurance purchased. The result is in agreement with the findings of Afroz et al. (2017) in Malaysia; as well as Chikaire et al. (2015) in Imo State, Nigeria who reported that the farm incomes or savings of a farmer are vital factors in accessing and using formal agricultural insurance.

The overall result of the analysis implied that the socio-economic factors significantly influenced the extent of the use of the Nigeria Agricultural Insurance Scheme by farmers. Hence, the null hypothesis was rejected and the alternative accepted. The null hypothesis was rejected since the $\mathrm{Chi}^{2}$ value of 45.26 at 0.05 level of probability was higher than the tabular value of 16.919.

Table 2: Socio-economic factors that influenced access to agricultural insurance scheme by small-scale farmers

\begin{tabular}{lrrrr}
\hline Variables & Coefficient & Standard error & t-value & p-value \\
\hline Age & $0.0243705^{* *}$ & 0.0111108 & 2.19 & 0.028 \\
Gender & 0.322401 & 0.2014236 & 1.60 & 0.109 \\
Awareness of AIS & $0.6224981 * *$ & 0.303463 & 2.05 & 0.040 \\
Farming experience & 0.0098537 & 0.0090574 & 1.09 & 0.277 \\
Household size & 0.2032411 & 3.212203 & 0.063 & 0.999 \\
Access to credit & 0.323401 & 0.2014736 & 1.61 & 0.108 \\
Marital status & $-.2562593 * *$ & 0.1234254 & -2.08 & 0.038 \\
Cooperative membership & 0.1390038 & 0.1117625 & 1.24 & 0.214 \\
Past experience with risk & -0.0683328 & 0.2046652 & -0.33 & 0.738 \\
Income & $1.51 \mathrm{e}-07 * *$ & $6.33 \mathrm{e}-08$ & 2.39 & 0.017 \\
Constant & $-1.785279 * * *$ & 0.5310414 & -3.36 & 0.001 \\
\hline
\end{tabular}

$\mathrm{LR} \mathrm{chi}^{2}(1)=61.92 * * *$

Prob $>\mathrm{Chi}^{2}=0.0000$

$* *$ and $* * *$ variables significant at $10 \%$ and $5 \%$ probability level respectively

Source: Field Survey, 2018 
Table 3: Factors that determine the extent of use of Nigeria agricultural insurance scheme (NAIS)

\begin{tabular}{lrrrr}
\hline Variables & Coefficient & Standard error & t-value & p-value \\
\hline Age & $10057.22^{* *}$ & 4561.468 & 2.20 & 0.027 \\
Gender & -28199.61 & 84491.08 & -0.33 & 0.739 \\
Household size & 0.006496 & 5.924305 & 0.00 & 0.739 \\
Marital status & $-105753.3^{* *}$ & 50572.56 & -2.09 & 0.999 \\
Awareness of AIS & $256893^{* *}$ & 125512.1 & 2.05 & 0.041 \\
Extension contact & 57364.2 & 45983.25 & 1.25 & 0.212 \\
Membership in coop. & 133461 & 83250.8 & 1.60 & 0.109 \\
Distance to the NAIS office & 4066.418 & 3722.32 & 1.09 & 0.275 \\
Income & $0.0624458^{* *}$ & 0.0259563 & 2.41 & 0.016 \\
Constant & $-736750.6^{* * *}$ & 216918 & -3.40 & 0.001 \\
\hline
\end{tabular}

Wald chi2 (9) $=45.26 * * *$

Log likelihood $=-1612.88$

Prob $>$ chi $2=0.0000$

** and $* * *$ significant variables at $10 \%$ and $5 \%$ probability level respectively

Source: Field Survey, 2018

\section{CONCLUSION AND RECOMMENDATION}

Agricultural risk is a global phenomenon; however, the magnitude of its negative impacts on small holder farmers varies depending on farmers' awareness, perception, access and the ultimate subscription to agricultural insurance. Investment in agriculture in the area of agricultural insurance especially among the smallholder farmers cannot be emphasized considering the uncertain and risky nature of the enterprise. Smallholder farmers' risk minimization through affordable insurance schemes is one of the surest ways of boosting farmers' confidence in their farming enterprise as well as enhancing the food security status of the nation and the overall agricultural development especially in the developing countries. The major findings of this study are in tandem with the available global evidence particularly in the developing countries that show limited awareness and access to affordable agricultural insurance packages among small scale farmers. Government policies should be directed towards absorbing and reducing the shocks of the smallholder farmers. Also, Government and other state actors should intensify efforts towards increased farmers' awareness of the insurance scheme and also increase farmers' participation through input subsidy provision, so as to free more farm income for agricultural insurance subscription and its sustainability.

\section{Acknowledgments}

The authors acknowledge the constructive criticisms and contributions by the staff and post graduate students of Department of Agricultural Economics, University of Nigeria, Nsukka, whose superb inputs helped reshaped the article.

\section{REFERENCES}

ADAH, O. C., CHIA, J. I., \& SHAIBU, M. U. (2016). Assessment of rural farmers' attitudes toward agricultural insurance scheme as a risk management strategy in Kogi State, Northcentral Nigeria. Journal of Economics and Sustainable Development, 7 (14), 12-19.
https://www.iiste.org/Journals/index.php/JEDS/article /view/31986/32856

AFROZ, R., AKHTAR, R., \& FARHANA, P. (2017). Willingness to pay for crop insurance to adapt flood risk by Malaysian farmers: An empirical investigation of Kedah, International Journal of Economics and Financial Issues. $\quad 7(4), \quad$ 1-9. https://www.econjournals.com/index.php/ijefi/article/ view/4355

AINA, O. S., \& OMONONA, B. T. (2012). Nigerian agricultural insurance scheme (NAIS): Prospect, achievement, and problems. Global Advanced Resources Journal of Agricultural Science, 1(5), 97103.

http://garj.org/garjas/7/2012/1/5/nigeria-agriculturalinsurance-scheme-nais-prospect-achievement-andproblems.

AKINOLA, B. D. (2014). determinants of farmers' adoption of agricultural insurance: the case of poultry farmers in Abeokuta metropolis of Ogun State, Nigeria. British Journal of Poultry Sciences 3 (2), 3641. https://idosi.org/bjps/bjps3(2)14.htm

CHANTARAT, S., MUDE, A. G., BARRETT, C. B., \& CARTER, M. R. (2013). Designing index-based livestock insurance for managing asset risk in northern Kenya. Journal of Risk and Insurance, 80(1), 205237. 6975.2012.01463.x

CHHIKARA, K. S., \& KODAN, A. S. (2012). National agricultural insurance scheme (NAIS) in India. Management and Labour Studies, 37(2), 143-162. https://doi.org/10.1177/0258042X1203700205

CHIKAIRE, J.U., TIJJANI A., R., \& ABDULLAHI K. A. (2015). The perception of rural farmers of agricultural insurance as a way of mitigation against climate change variability in Imo State, Nigeria. International Journal of Agricultural Policy and Research, 4 (2), 1721. https://journalissues.org/ijapr/abstract/chikaire-etal-february-2016/

COLE, S., GINÉ, X., TOBACMAN, J., TOWNSEND, R., TOPALOVA, P., \& VICKERY, J. (2013). Barriers to household risk management: evidence from India. 
American economic journal of applied economics, 5(1), 104 -135. http://dx.doi.org/10.1257/app.5.1.104

ELERI, O. E., UDUKA, I. K., AKUTO, N., ONUVAE, P., \& ANWARA, O. (2012). Towards a climate-based agricultural insurance reform in Nigeria. Workshop on legal and regulatory frameworks for agricultural insurance reform in Nigeria - Protecting Nigeria's farmers from climate change, Transcorp, February 27, 2012. pp. $1-53$.

ELLIS, E. (2017). Willingness to pay for index-based crop insurance in Ghana. Asian Economic and Financial Review, 7(7), 700-721. $\underline{10.18488 / \text { journal.aefr.2017.77.700.721 }}$

EPETIMEHIN, F. M. (2012). Agricultural insurance in Nigeria and economic impact. International Journal of Agricultural Economics, Management, and Development. 1(1), 56-71.

FAlOLA, A., AYINDE, O. E., \& AGBOOLA, B. O. (2013). Willingness to take agricultural insurance by cocoa farmers in Nigeria. International Journal of Food and Agricultural Economics, 1(1), 97-107. $\underline{10.22004 / a g . e c o n .156837}$

FRNOG. (2009). Legal notice on publication of 2006 census final result. Federal republic of Nigeria official gazette,

96(2).

https://gazettes.africa/archive/ng/2009/nggovernment-gazette-dated-2009-02-02-no-2.pdf

FOOD AND AGRICULTURAL ORGANIZATION (FAO) (2006). Compendium of food additive specifications: joint FAO/WHO expert committee on food additives: 67th meeting 2006. Food and Agriculture Organization of the United Nations. http://www.fao.org/3/a-a0675e.pdf

IBITOYE, S. J. (2012). Assessment of the levels of awareness and use of agricultural insurance scheme among the rural farmers in Kogi State, Nigeria. International Journal of Agricultural Science, Research and Technology, 2(3), 143-148. http://ijasrt.webs.com/2012.3-7.143-148.Ibitoye, ijasrt 50-01.pdf

KADP (2011). Kogi State agricultural development program annual report. planning, monitoring and evaluation department, Lokoja. $15 \mathrm{pp}$.

KUMAR, D. S., BARAH, B. C., RANGANATHAN, C. R., VENKATRAM, R., GURUNATHAN, S. \& THIRUMOORTHY, S. (2011). An analysis of farmers' perception and awareness towards crop insurance as a tool for risk management in Tamil Nadu. Agricultural Economics Research Review, 24, 37-46. 10.22004/ag.econ.109413

MAHUL, O., \& STUTLEY, C. J. (2010) Government support to agricultural insurance: challenges and options for developing countries. Washington D.C., World

Bank. https://openknowledge.worldbank.org/handle/10986/ $\underline{2432}$

NNADI, F. N., NNADI, C. D., CHIKAIRE, J., UMUNNAKWE, P. C., \& IHENACHO, R. A. (2013). Analysis of rural cassava farmers' participation in the Nigeria agricultural insurance scheme in Imo State, Nigeria. Global Journal of Science Frontier Research Agriculture and Veterinary, 13(11).
https://journalofscience.org/index.php/GJSFR/article/ download/958/823/

NWANI, A. T., \& OMANKHANLEN, A. E (2019). Insurance receivables and economic growth: the case of Nigeria. Journal of Physics: Conference Series 1378 (2019) 042093: 1-15. 10.1088/1742$\underline{6596 / 1378 / 4 / 042093}$

OGUNMEFUN S. O., \& ACHIKE A. I. (2015). Socioeconomic characteristics of rural farmers and problems associated with the use of informal insurance measures in Odogbolu local government area, Ogun state, Nigeria. Russian Journal of Agricultural and Socio-Economic Sciences. 38(2), 3-14. 10.18551/rjoas.2015-02.01

HALLEGATTE, S., VOGT-SCHILB, A., ROZENBERG, BANGALORE, M., \& BEAUDET, C. (2020) From poverty to disaster and back: a review of the literature. Economics of Disasters and Climate, 4, 223-247 https://doi.org/10.1007/s41885-020-00060-5

OKOFFO, E. D, DENKYIRAH, E. K., ADU, D. T., \& FOSU-MENSAH, B. Y. (2016). A double-hurdle model estimation of cocoa farmers' willingness to pay for crop insurance in Ghana. Springer Plus. 5(873). https://doi.org/10.1186/s40064-016-2561-2

PELKA, N., MUSSOFF, O., \& WEBER, R. (2015). Does weather matter? How rainfall affects credit risks in agricultural microfinance. Agricultural Finance Review, 75(2), 194-212. https://doi.org/10.1108/AFR$\underline{10-2014-0030}$

PRAGER, D. L., SARAH, T., \& RON, D. (2018). Economic returns to farming for U.S. farm households. Economic Research Report, Number 254. U.S. Department of Agriculture, Economic Research Service.

https://www.ers.usda.gov/webdocs/publications/8970 2/err-254.pdf?v=0

SCHAFFNIT-CHATTERJEE, C. (2010). Risk management in agriculture: towards market solutions in the EU. Germany: Deutsche Bank Research. Frankfurt am Main. September 17, 2010. https://www.farm-

d.org/app/uploads/2019/05/Deutsche-Bank-ResearchRisk-Management-in-Agriculture-091710.pdf

SHERRICK, B. J., BARRY, P. J., ELLINGER, P. N., \& SCHNITKEY, G. D. (2004). Factors influencing farmers' crop insurance decisions. American Journal of Agricultural Economics, 86(1), 103-114. 10.1111/j.0092-5853.2004.00565.x

SIBIKO, K. W., VEETTIL, P. C., \& QAIM, M. (2018). Small farmers' preferences for weather index insurance: insights from Kenya. Agriculture \& Food Security, 53(7) (2018). https://doi.org/10.1186/s40066-018-0200-6

SKEES, J. R. (2008). Challenges for use of index -based weather insurance in lower income countries. Agricultural Finance Review, 68(1), 197 - 217. http://dx.doi.org/10.1108/00214660880001226

TSIKIRAYI, C. M. R., MAKONI, E., \& MATIZA, J. (2014). Analysis of the uptake of agricultural insurance services by the agricultural sector in Zimbabwe. Journal of International Business and 
Cultural Studies, 22(5), 36-45.

https://www.aabri.com/manuscripts/121360.pdf

UKWUABA, I. C., OWUTUAMOR, B. Z. \& OGBU, C. C. (2020). Assessment of agricultural credit sources and accessibility in Nigeria. Review of Agricultural and Applied Economics 23 (2), 3 - 11. 10.15414/raae.2020.23.02.03-11 